\title{
Marine Gheno
}

\section{The FEMENist Connection:}

\section{Ruptures and Agency in FEMEN France}

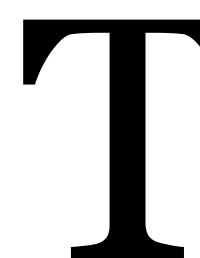

he logo adopted by FEMEN is the letter $\Phi$, "F" in Cyrillic, handdrawn to resemble a chest with two breasts (see fig. 1). The group announces already with this iconography a desire to explore nudity as an activist practice. FEMEN activists are known (and famous) for inscribing the messages of their protest directly on their bare breasts and other parts of their bodies, thus claiming nudity as a way towards freedom through a "naked war" (fig. 2).

The use of multiple languages on FEMEN's demonstration signs in France, such as English and French, Arabic, Russian, Ukrainian and more depending on the topic (fig. 2), enables the group to draw a wider, and transnational, audience. FEMEN has been vocal in favor of abortion rights and gay marriage, in protest against the extreme-right party Front National, and the oppression of Muslim women by Islamism. The group claims to defend a universal and transnational new feminism promoting all women's liberation using breasts as weapons. While successfully bringing women issues to the forefront of the mainstream media, their method is also criticized for embodying and reproducing Western standards of beauty as well as imposing Western 
neoliberal views of freedom on the non-Western other, namely Muslim women.

Nudity as a form of activism is very powerful: "Because they disrupt sacrosanct dichotomies of public/private and visible/hidden, naked bodies constitute a uniquely explosive site of protest” (Eileraas 41). Such strategies coupled with knowledge of the media produce news-worthy images and an unforeseen coverage for FEMEN activists (Dalibert and Quemener). FEMEN deliberately utilizes mainstream media's objectifying eye on women to gain visibility, which causes an ambiguity - or a rupture - with regards to the group's feminist fight and ideals. How to articulate FEMEN's objectification of women's bodies within a "new feminism"?

This issue needs to be viewed from a different angle as well: activist women strategically appropriating media methods of visibility also challenge and subvert the power structure of domination over women. FEMEN's agency is fully embodied through its provocative and transgressive body politics and its guerilla rhetoric which depict powerful women fighting for their cause at all costs (Dalibert and Quemener).

In this article, I will argue that FEMEN carries an inherent ambiguity which is particularly visible in France, a context wherein the women's movement has a long history of activism and theory. FEMEN actions are both beneficial and detrimental to feminism as they present the media with eroticized militant women while empowering such representations of women. In the vein of popfeminism and girl power media culture, FEMEN contributes to a transformation of contemporary feminist activism in continuity with feminist 
claims to agency, and in rupture with feminist criticisms of neoliberal commodification of women.

First, I will briefly introduce the FEMEN movement's history and goals as well as their popular methods of activism to get media attention. Then, I will turn to the feminist reception of the group in France. FEMEN actions trigger strong criticism from the public, feminists and thinkers who situate the polemical bare-breasted interventions in between radical and ridicule, discrediting feminist thought and, possibly, ideals. However, FEMEN also contributes to a contemporary feminism embodying empowerment and agency in transgressive ways. In conclusion, I will propose to envision the disruption and transgression offered by FEMEN both in the public sphere and the feminist

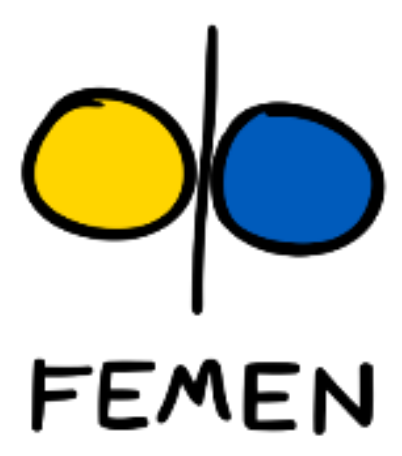

Figure 1: the FEMEN logo; public domain, Wikipedia.org, 2012; Web; 6 Oct. 2014.

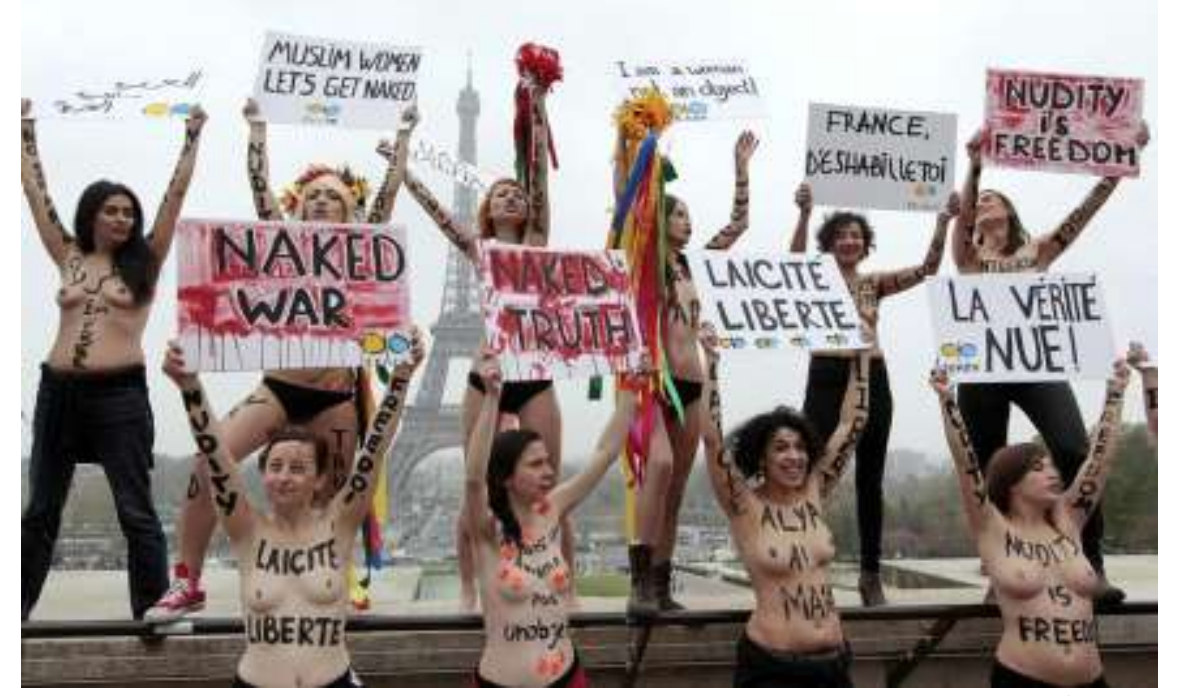

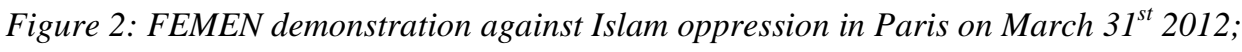
FEMEN.org; 2012; Web. 6 Oct. 2014. 〈FEMEN.org/uploads/gallery/Trl584LA1I.jpeg> 
sphere as a transformation of political activism and militant actions, especially in the political context of France.

\section{FEMEN: Origins}

FEMEN started in Ukraine with Oxana Shachko, Sasha Shevchenko and Anna Hutsol (O'Keefe). The group was instigated by the latter, an economist and former political sciences student, who appears as the off-stage organizer: she never shows parts of her body during demonstrations. Such a role in in the FEMEN group illustrates the mise-en-scène required for each protest and a separation between "thinkers" and "doers" amongst the activists, at least during the first years of the group. Another shadow organizer, Viktor Svyatski, was unveiled in the documentary Ukraine is not a brothel by Kitty Green (2013). Portrayed as Anna Hutsol's best friend, he was soon rejected by the activists for his patriarchal ways. The presence of a man with a misogynistic and dictatorial ${ }^{1}$ attitude towards the female activists gave ground to the argument that FEMEN is not a credible political group.

The primary local goal of FEMEN was to create a strong feminist reaction in Ukraine against sex tourism and the Church's patriarchal domination over women. The activists' response to women's oppression is to reclaim the female

\footnotetext{
${ }^{1}$ In the documentary, Svyatski proves quite patriarchal and misogynistic about FEMEN activists. According to him: “They don't have the strength of character. They don't even have the desire to be strong. Instead, they show submissiveness, spinelessness, lack of punctuality, and many other factors which prevent them from becoming political activists. These are qualities which it was essential to teach them." (quoted in Macnab). Since then, FEMEN leader Inna Shevchenko and other activists have cut ties with Svyatski while accepting that he is in the past of FEMEN (see Girard "Viktor Sviatski").
} 
body by demonstrating bare-breasted, thus creating representations of strong and enthusiastic women which, according to Christine Fauré, echoes their cultural background of Soviet era art; for example, the sculptures "The People of USSR" by Joseph Tchaïkov and “Worker and Kolkhoz Woman" by Vera Mukhina for the International Exposition of Paris in 1937.

In addition, FEMEN adopted the flower wreath “vinok," symbol of women's virginity, independence and freedom in Ukrainian Folklore, which situates the group within its cultural background through strong and positive imagery (Fauré). While exposing nudity is already morally shocking especially in the context of traditionalist and conservative Ukraine, FEMEN adds to the provocation with colors, flowers, energy, and a playful youthfulness in direct opposition with conservative views of society, politics, and even (an older view of) feminism.

Rejuvenating political action makes FEMEN protests particularly visible and attractive to the media through powerful and beautiful images. Thanks to media strategies, FEMEN could quickly reach a wider audience and give more validity to its protest by being more visible. The group rapidly spread around the world with now several branches in France, Germany, Turkey, Quebec, and Israel; Paris being the official headquarters of the transnational organization. FEMEN extended its local roots to a transnational and global scope through its use of multiple languages and communication media. FEMEN aspires to a transnational and universal new feminism exploring women's body and sexuality for empowerment. 


\section{Political stance}

The group labels itself "sextremist" due to the deliberate use of activists' bodies and sexuality for protest. The description of the group on FEMEN.org (available in English and Russian, not in French) places the body at the center of its struggle to free women from patriarchy:

And so you turn your body against this injustice, mobilizing every body's cell to struggle against the patriarchy and humiliation. You tell the world: Our God is a Woman!

Our Mission is Protest!

Our Weapons are bare breasts!

And so FEMEN is born and sextremism is set off.

With such statements, FEMEN cuts ties with an older feminism which perceives the body as a private space and opposes all commodification of women's sexuality. FEMEN's use of bare breasts embraces the objectification of women's body as weapons for change; a support for visual action as well as an appropriation of nudity as a space of empowerment and freedom: "FEMEN is the special force of feminism, its spearhead militant unit, modern incarnation of fearless and free Amazons" (femen.org). The discourse of FEMEN is close to third-wave feminism in favor of a sex-positive agenda fused with media and advertising codes to ensure the group's success. That way, it can also be associated with "girl power media culture:"

As a commodified social movement, girl power media culture takes the third-wave desire for power through sexuality and combines it with the capitalistic 'sex-sells' imperative to produce a discourse in which sexuality equals power over men, as well as large revenues for sex-positive performers and those who profit from their public display of sexuality. (Zaslow 62) 
FEMEN embraces the commodification of women's sexuality as an empowerment tool over men (including policemen arresting the activists), against domination, and also as a media tactic to gain visibility. FEMEN protests are staged performances where activists have a specific spot to reach, specific positions to hold and messages to shout. The activists perform positions of powerful women, warriors in the name of women, and also strategically ensure strong images to be spread by media. However, the monetary aspect doesn't exactly fit FEMEN activists, who don't receive the financial outcomes of pop singers mentioned by Zaslow. ${ }^{2}$

Also, FEMEN members do not claim to be artists or performers (even though it is a part of their practice) but activists, a notion that is no longer necessary in the younger generation's take on feminism. For the girls interviewed by Emilie Zaslow, to be a feminist in girl power media culture is about being a confident woman acting on her ambitions and willing to succeed in society and life. Feminism is dissociated from necessary activism that recalls radical feminist movements from the 1960 s and 70s. Pop singers, TV show hosts, or actresses are perceived as feminists because of their choices to be open lesbians or to address women's abuse publically (examples would be Ellen Degeneres or Oprah Winfrey). FEMEN comes from the same generation of younger women envisioning freedom on the media scene, playing with the codes of advertising

\footnotetext{
2 FEMEN finances remain a closeted topic, as O'Keefe details in her article about SlutWalks and FEMEN. The French journalist Cordier managed to get the accounts of FEMEN France stating it is funded by donations and sales of products branded FEMEN. No public subventions come into play and the $10669 €$ donation received in 2013 comes from individuals giving $500 €$ maximum which excludes the hypothesis of monopoly by rich donators (at least in France).
} 
to display women's bodies and sexuality. By bringing back necessary activism, FEMEN changes Zaslow's conception of third wave feminism, or adds to it. FEMEN seems to stand between pop culture marketing standards and a risky radical practice which provide some sort of fame but no financial benefits (as we are led to believe at this point).

In France, the rock magazine Les Inrockuptibles situates FEMEN in popfeminism, a modern and young manifestation of feminism to which contemporary young women can relate, unlike radical feminism perceived as obsolete and remote (Brouze and Greusard; Bard). FEMEN invests the space of global communication through social networks and a constant use of Englishthe language of globalization-supplemented by other languages during protests in order to target primarily a younger audience. The rest of the population is less likely to feel a connection with the experiences and fight of a group speaking another language than French, and adopting marketable tactics to promote women's liberation. One activist evokes the appeal of FEMEN's pop and modern image using advertising codes3: with such tactics, there is no need for theoretical manifestos; the thinking is inscribed within the practice. In this context, appropriating marketable modes of visibility in the media is an attractive argument for younger activists who identify with media culture and want to participate in feminism only if it changes its image.

3 Activist Julia states : "une image totalement pop, actuelle et d'une extrême intelligence. Elles utilisaient les codes de la publicité avec une image, un slogan et résumaient dix pages de manifeste en une image extrêmement efficace" [an image that is totally pop, current and extremely intelligent. They were using advertising codes with one image, a slogan, and summed up ten pages of manifest into an extremely efficient image] (quoted in Brouze and Greusard, my translation). 
Popfeminism refers to a contemporary form of feminism theorized first in Germany with women artists using elements of pop culture to articulate social criticism:

Popfeminism in its broadest sense playfully approaches traditional feminist interests by uniting gender issues, women's rights, and body politics with elements of popular culture inspired in particular by music, new media, and fashion. Popfeminism utilizes the symbols of global pop culture in order to create a critical, local, and individual subculture, a new public and visible space of resistance defined, not constrained, by gender. (Smith-Prei 20)

Popfeminism formulated this way is closely linked to cultural productions, from novels to rap songs, by women also known in the public sphere as TV hosts (Sarah Kuttner and Charlotte Roche) or academics (Lady Bitch Ray). These authors explore notions of femininity, sexuality, and vulgarity to re-appropriate their bodies through experimentation with media culture. The playfulness involved as well as a detachment from stricter feminist ideals evidenced by adopting liberation elements of neo-liberalism (embracing the idea of choosing to display one's body and to sell it) echo greatly FEMEN strategies. However, FEMEN tactics do not incorporate the intellectual background that German popfeminists do: as Smith-Prei notes, the term "German pop" used since the 1960 indicates a subversive subculture inscribing in its productions a strong criticism of global and local domination which influenced directly today's popfeminists. FEMEN's insistence on image to reinforce the visibility of feminism in popular media culture sometimes poses the question of content.

FEMEN has been criticized many times for its lack of political agenda, multiplying the reasons for protests from opposing homophobia to the closure 
of a zoo, or in support of the Japanese disaster victims (Pyzik; Timmerman). The leader and spokesperson for FEMEN France, Inna Shevchenko, fails to deliver a clear direction for her group, and tends to charge her declarations with underlying essentialist or condescending comments. For instance, she explains the unattractive image of contemporary feminist collectives in France by stating that feminists "look like men": "ce ne sont pas des mouvements faits pour les jeunes femmes, mais pour des femmes intellectuelles qui ressemblent à des hommes, qui nient la sexualité, le fait qu'une femme puisse être féminine" [they are not movements made for young women, rather for intellectual women $w h o$ look like men, who deny sexuality, and the fact that a woman can be feminine] (quoted in Chollet, my translation, emphasis added).

Shevchenko's declaration is quite problematic in terms of political stand, quasi anti-feminist, in asserting that feminists "who look like men" are neither interesting nor relevant. Even if the initial message is to offer new forms of activism likely to correspond to today's reality for younger women, the underlying sexism is counterproductive. The essentialist binary opposition of women's beauty against men's seriousness brings back stereotypes of women's lack of intellect and injunction to be attractive. Such a statement contradicts the endeavor of FEMEN to rejuvenate feminism and evidences a disconnection from previous French feminist history.

Consequently, the FEMEN shock-actions take up all media attention for potentially no (feminist) message to deliver. According to Liza Babenko, an activist and art critic in Ukraine, FEMEN is successful at setting up pop shows 
but cannot be considered a "serious feminist group with political feminist tasks and practical feminist achievements" (Pyzik 35). FEMEN is such a media phenomenon that feminist groups which get less coverage are now asked by the press what they think of FEMEN's actions, and not what their own claims and stances are (Timmerman).

\section{FEMEN in France}

Inna Shevchenko found political asylum in France where she is the leader of the FEMEN French branch (Dalibert and Quemener). She exemplifies Western femininity as a young, white, blond, slim and conventionally attractive woman, which corresponds to the group media-driven tactics. FEMEN Ukraine, deemed criminal in its own country, has been closed down and its members are now scattered around Europe looking for asylum. The turbulent past of Shevchenko (she notably sawed down a cross in Kyiv in support of the Russian feminist punk band Pussy Riot fighting against the hegemony of the Church) is narrated in French mainstream media using the terminology of resistance, war, and spectacular heroism. It crafted "l'image d'une activiste à la fois érotique et combattante, ancrée dans la mythologie de l'Amazone" [the image of an activist as both erotic and fighting, rooted in the mythology of the Amazon] (Dalibert and Quemener 170, my translation).

Much like Fauré's echo to Soviet era images of strong women, Amazon symbolism inscribes FEMEN in an imagery of powerful feminine figures that remains imaginary; neither images link FEMEN with any political history or 
heritage. FEMEN activists are viewed (and declare themselves) as revolutionary and new-as if no women had fought for rights and agency before. Shevchenko embodies FEMEN uprootedness, severed from the past, and also represent its pull towards the global world as a new space to inhabit, to call home.

France would appear as the perfect nexus to establish a movement of protest for women's freedom given the country's cultural history of revolution and strikes. The mural set up by street artist COMBO in Paris illustrates the potential connection between the history of revolution, the leading force of “Marianne”, and FEMEN's feminist fight (Rojo and Harrington; see fig. 3). Entitled "FEMEN Leading the People (or the street's tribute to feminism)," the mural reinterprets the famous Delacroix painting "La liberté guidant le people" (fig. 4) illustrating the revolution of 1830 with a strong female leader, barebreasted, fist in the air and ready to fight as the symbol of the Republic; la Marianne. This tribute from the street shows a desire of acceptance of FEMEN's feminism by the people, a desire of inscribing FEMEN's fight within France's history. It also highlights the group's popular activism in the sense of occupying the streets to protest, using methods available to the people. However, FEMEN's provocation seems to divide people more than leading a revolution, and never links its "breasts as weapons" tactics to previous ones in history (the braburning image of 1970 s feminist protests, or African women exposing nudity to remind men they also come from that body; see Bard). 


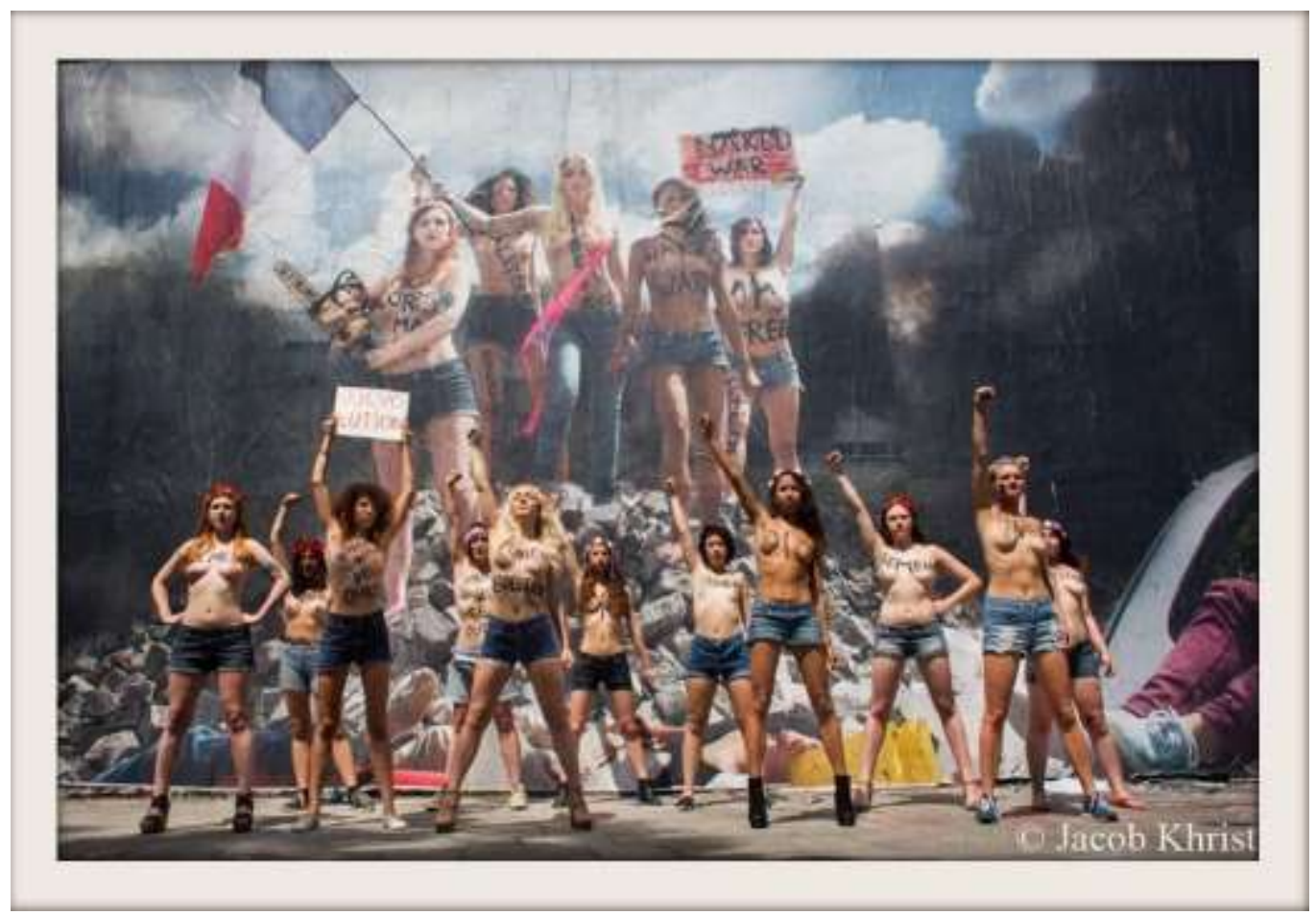

Figure3: Mural by Paris street artist COMBO and FEMEN activists posing on July 14 2014. Photo by Jacob Khrist; Canalblog Jourstranquilles; 16 July 2013; Web; 6 Oct. 2014. <http://jourstranquilles.canalblog.com/ archives/2013/07/16/27652512.html>

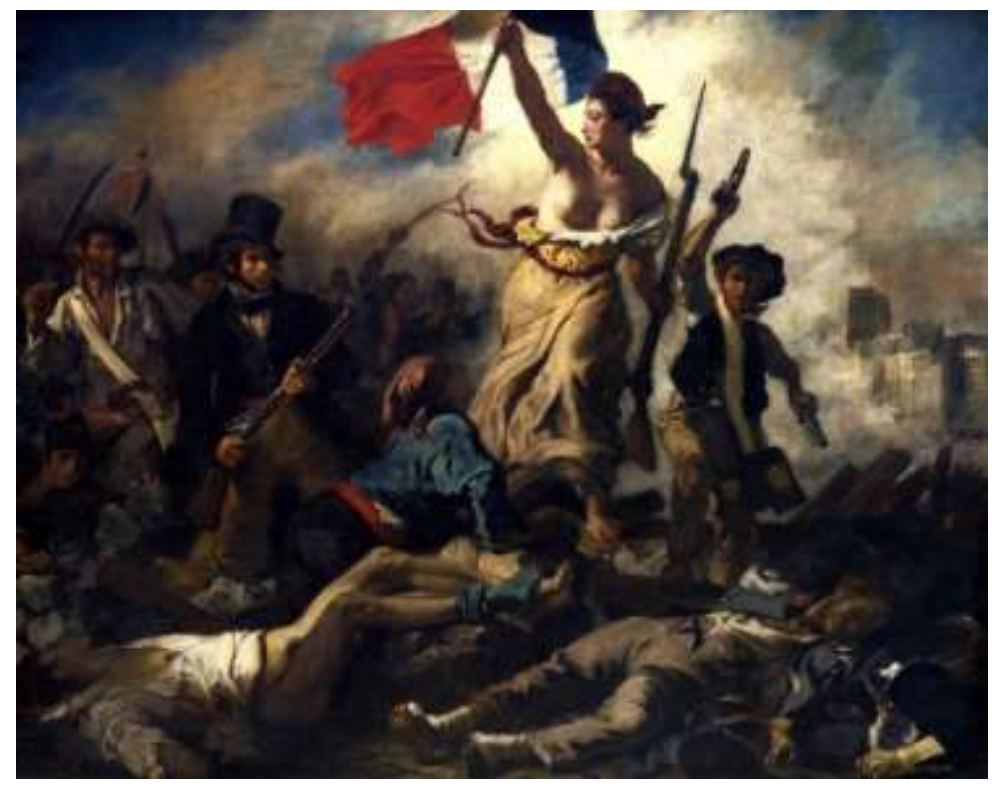

Figure 4: La Liberté guidant le peuple; Eugène Delacroix; 1830; Musée Louvre-Lens; Wikimedia Commons; Web; 6 Oct. 2014. 
In Western globalized media culture, the provocative protest method of displaying messages on naked bodies creates a striking effect: on every image that one can find on the internet and on the news, whether it shows an activist in an empowered pose or arrested (sometimes tackled) by a policeman, the message inscribed on the bodies is always on the picture (see fig. 5). The words cannot escape the image, they are inextricably linked. The awkwardness created by naked bodies in a public performance act juxtaposed to strict uniforms of bodies in charge of control and restrain is also a common component of the media coverage of FEMEN. Is it joy on the policeman's face to encounter unusual protesters displaying eroticized bodies? Is it discomfort created by empowered nudity? FEMEN actions keep provoking disturbance, be it playful as it seems in figure 5, or more violent as they are forcefully removed and insulted by some members of the public.

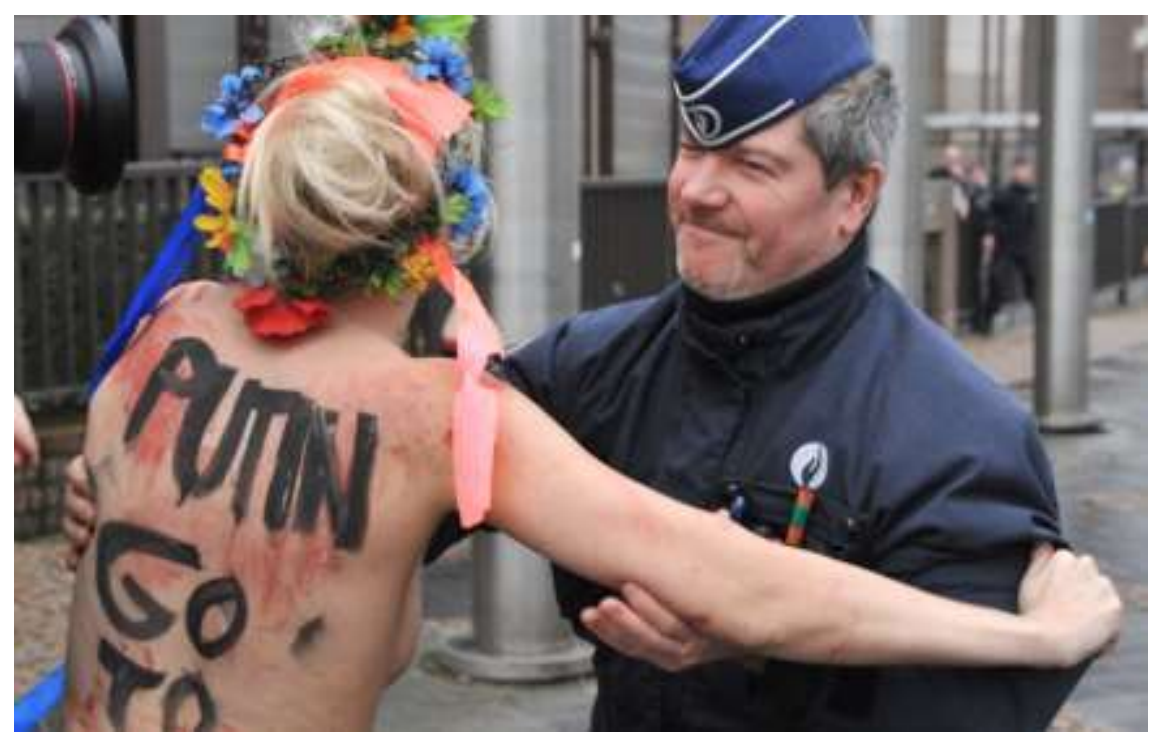

Figure 5: FEMEN activist restrained by a police officer in Brussels. Photo by Georges Goubet; 20min.ch; 21 Dec. 2012; Web; 6 Oct. 2014; 〈www.20min.ch/ro/news/monde/story/10278693〉 
Such tactics require both attractive bodies - fitting Western standards for media - and courage. The public spectacle attracts attention and creates images, symbolic scenes of martyrs being victims of the authorities manhandling naked women, as well as illustrations of the violence FEMEN activists face during each performance. The strategy is carefully designed according to media codes in order to get as much publicity and visibility as possible - and the cameras always abound. Symbolically, the activists become fighters, warriors for the cause of women worldwide, fighting authority and censorship. The activists' empowerment and agency come first from reclaiming their bodies as emotional, personal, and political sites; they put on a show of martyrdom during the performances in which they only appear as victims to reassert their power and relentlessness. They re-enact the violence against women that is entrenched within society by producing caricatural images of nude women - in their most "pure" and natural form - oppressed by men in charge of order and control.

FEMEN actions get the attention of media which post and print large pictures of the transgressions of the partially naked activists. 4 In return, the media attention provides some protection during the demonstrations: no one will publicly and physically attack protesters on camera (Timmerman). It remains difficult to measure the effectiveness of the method on political discourses, or the judicial system.

\footnotetext{
4 The main newspapers (Le Monde, Libération, Le Figaro) and TV channels (France TV, TF1, Canal+) cover widely the actions by FEMEN in France. As an example, a search on LeMonde.fr shows 30 articles with "FEMEN" in their title during the year of 2014. An average of over two articles a month on the feminist group sustains its presence in mainstream media.
} 
One example illustrates the power of public outcry: in October 2012, FEMEN activists protested against the verdict of a gang rape trial where a few of the accused got suspended sentences and the rest were acquitted (Clairouin and Barthet). The trial was already controversial and FEMEN contributed to the polemic and the media visibility of the verdict. After a second trial a few months later, the sentences came to be heavier, potentially due to the pressure of the public outrage. FEMEN does contribute to the visibility of feminist battles against women's abuse, and to current public debates. However, for contemporary feminist groups, it is still difficult to give credit to FEMEN's actions embodying women's objectification instead of opposing it.

\section{French feminist reception of FEMEN}

FEMEN actions are transgressive even within feminist thought: they are criticized by contemporary feminist groups and thinkers largely because of their use of the male gaze for their actions in the nude. FEMEN seeks empowerment and agency through a re-appropriation of women's image via sensuality, sexuality, and sexiness. This stance revives the anti-victimization argument from third-wave feminism criticizing second wavers for their tendency to see women as victims of patriarchal rules at home, at work, and in society as well as victims of the male gaze in the media, the news, and cinema.

According to Theresa O'Keefe, FEMEN represents the "uncritical embodiment of hegemonic, heteronormative corporealities that are unquestionably rooted within patriarchal and capitalist values" (5) in the name 
of choice and freedom - terms easily associated with neo-liberalism. Ovidie, a former French pornography actress now director and writer, describes on her blog FEMEN's use of perfect bodies as media capital rather than "weapons." The types of bodies displayed on the FEMEN website and during protests are mostly white, blond, slim, and able-bodied which corresponds to Western media codes of beauty for marketability purposes.

The feminist group Les TumulTueuses criticized FEMEN in an online open letter “Ha, les FEMEN...” for promoting essentialist feminism through normative images of femininity and implicitly rejecting a large portion of women who do not fit their criteria. Once confronted with the issue, FEMEN posted on Twitter pictures of activists with non-normative bodies; larger women, bodies with different skin colors, and a few men. This necessary criticism against FEMEN demonstrates a lack of reflection from the group's organization on the multiplicity of shapes, sizes, and skin colors of women around the world, including France, and/or a deliberate decision to display specific bodies for consumerism reasons. A transnational feminist group with no inclusion of diversity reproduces a hierarchy of white/slim/able-bodied women over all others and counteracts the claim to fight for all women's freedom.

Shevchenko claims that she wants to separate FEMEN from traditional views of women's bodies and use the provocation factor of the naked body to both attract the eye and free women from it (Desnos). The performances set out by FEMEN should then parody by exaggeration the obscenity that the female body represents in public discourses, and ultimately free women from this image. 
According to O'Keefe, there is in fact little parody happening during the staged protest since there is no critique of the "[hegemonic] masculine ideals of female bodies" (5) and FEMEN needs "the male gaze" to "sell a message" (10). Despite our observation of a parodic reproduction of men dominance over women in the interaction between nude activists and policemen, FEMEN body aesthetics correspond to a limited ideal of beauty.

This contradiction associated with girl power media culture is comprised within the idea of sporting, enjoying and displaying a "sexy" body by choice, empowered by a neo-liberalist conception of freedom through individualization and consumption. FEMEN neo-liberal protest tactics tend to reproduce the power structure of women's commodification instead of critiquing it, they do not seem to challenge the status quo. These critiques push aside the empowerment of naked activism to re-appropriate bodies as political canvases, and sites of subjectivity/agency - or decide it does not outweigh the detrimental compliance with the commodification of women's bodies from a group displaying colonizing methods on other cultures.

The criticism of cultural discrepancy is the strongest against FEMEN in France. There is a gap of cultural awareness in the activists' practice which does not adapt to the public they address. FEMEN has been accused of Islamophobia and practicing a neocolonial feminism: white Western women claiming to educate Muslims about women's rights (Eileraas; Dalibert and Quemener). FEMEN actions in Turkey and North-African countries are not sensitive to the audience's cultural background where protesting bare breasted certainly creates 
shock and provocation, but also poses a real danger for the life of these women. Shevchenko declares that sextremist actions allow "to check each country for the level of its liberation," but it limits the definition of "liberation" to unveiling its skin and breasts, and imposes a Western-centric ideal on the rest of the world.

In addition, FEMEN infuriates local feminist groups which have not been consulted about their work and their needs from an international feminist aid (Timmerman). FEMEN imposes its ways as well as its ideals marked by Western feminine clichés about beauty, bodies, and how to empower oneself without taking into consideration cultural differences or local activism. If FEMEN is claiming to create tomorrow's feminism, why not associate its actions with today's feminism? Once again, we observe a lack of connections between FEMEN and feminist groups, be it in the present or the past.

Les TumulTueuses see infantilizing practices at work when FEMEN's activists assume that Muslim women need to be saved. Ovidie also warns against the disregard for cultural differences and the lack of reflection portrayed by FEMEN anti-Islam protests. Julia Kristeva contributed to the debate in 2013 to support FEMEN's initiatives to promote feminism and women's freedom, though she warned about the group's provocations being counter-productive in NorthAfrica (Daumas and Girard). The argument of counter-productivity in advancing women's rights and freedom reflects a criticism of FEMEN's antiintellectualization of its actions.

In the French context of immigration and marginalized mixed identities, Asma Guenifi as head of Ni putes ni soumises - a feminist group fighting for 
French Muslim women - indicates important lacks in FEMEN practices. She states that FEMEN does not demonstrate any knowledge of France's history of feminism including the different debates between essentialism and social construction of identity, or universalism and diversity. FEMEN propagates an "anti-patriarchal universalism" (Fauré) that does not complicate the constitution of the woman-subject according to religion, class, sexuality, race, or ethnicity, and therefore does not participate in the discussion of plurality and diversity within feminism. For Guenifi, the rejection of diversity within FEMEN practices is detrimental to other feminists groups rooted in the history and experience of everyday France.

The current political climate in France is charged with a conservative backlash which is giving less and less weight to feminist claims. Progressive sexuality politics adopted by the Socialist government - gay marriage adopted in May 2013, adding the discussion of gender in schools' biology textbooks, etc. - provoked large demonstrations by groups rarely seen in the streets: Catholics, conservatives, traditional family advocates... protesting against gay marriage, gender theories, and abortion. Their voices were highlighted by mainstream media as a strong counter-discourse to the government. Broadcasted in parallel to such news, FEMEN's nude radical actions supporting abortion while screaming "no God in my vagina" 5 become the very example of what reactionaries condemn. FEMEN blunt messages in English seem to illustrate the

\footnotetext{
5 FEMEN protested in Paris against a Spanish anti-abortion law on February $2^{\text {nd }}$ 2014, see
} Hélène Guinhut's report in Elle magazine. 
modern decadence or indecency claimed by the conservative backlash. FEMEN received many threats, insults, and violent reactions especially in that period. ${ }^{6}$ FEMEN actions, in that specific juxtaposition, fuel tensions and fail to deliver the feminist message to protect women's reproductive rights.

For some feminists, FEMEN uses ineffective methods in France: it provokes backlash and anti-feminist sentiments instead of feminist debates, it is rejecting intellectualization and feminist history, it ignores diversity, and nudity is not censored in France therefore FEMEN feeds the patriarchal capitalist pockets of mainstream media more than giving a voice to feminist critiques. There is no denying that FEMEN uses neoliberal tactics to gain the attention of the media which certainly is problematic within the feminist heritage, but there is still something to be said about the empowerment within its tactics.

Christine Bard offers a look at body politics used by the suffragettes and by FEMEN, insisting on the history of the body as a site for struggle. As we saw in the introduction, nudity as an activist practice triggers strong reactions because the body represents the frontier between private and public, intimacy and politics; exposing nude and empowered female bodies provokes uneasiness, moral tensions, and scandals. The transgression of nude activism broadcasted through mainstream media pinpoints the objectification of women. It also

\footnotetext{
${ }^{6}$ Christine Bard mentions the violence against FEMEN and specifically the demonstrations against gay marriage from which spawned two groups protesting against FEMEN (Homen for topless and masked men reasserting their dominance, and Antigone for young women in white dresses promoting purity and decency).
} 
provides empowered representations of women with agency to act on oppression and domination.

Women around the world have started to display powerful naked bodies online, labelled à la FEMEN, such as Aliaa Magda Elmahdy, the Egyptian art student posing naked with black stockings and red flat shoes who accompanied her picture with a text on freedom of expression. Her post participated to the Arab Spring in 2011 (Eileraas). She later joined FEMEN. Ai Xiaoming, a retired University professor and human rights' activist in China, also posted a picture of herself topless with a message painted on her breasts in support of the feminist activist Ye Haiyan. The latter had been harassed and arrested after denouncing rapes on school pupils by the school's headmaster (Bard).

The very act of displaying women's bodies in positions of power is an act of agency and subversion to the power structures in place which limit women to submission and passivity. FEMEN deploys its own marketing and consumerist tactics that are in rupture with radical feminist thought, but could also undermine neoliberalism by turning the object - women's bodies - into a subject, a product to sell into an agent fighting for political ideals no longer "sellable" through the same channels.

FEMEN is transgressive within feminism because it envisions feminist protests and visibility away from a critique of capitalism, and fully towards the exploitation of one's own body. Continuing in the same fashion, FEMEN sells tshirts and mugs with its name on it as a brand and thus resembles a co-optation of feminism by neoliberalism instead of a subversive reversal of women's 
commodification. Evidently, the group would benefit from additional reflection on race and religion, as well as on reproducing colonial domination. FEMEN activists detach themselves from the historical heritage of feminist political struggles both in practices and intellectual theorizations even though nude protests and claiming the body as a political site were used prior to the group's existence.

However, rejuvenating feminist practice appeals to younger activists who welcome dynamic and visible actions as well as the transnational scope of FEMEN methods rooted in contemporary modes of communication. FEMEN's surfing on taboos, anti-political-correctness, and neoliberal tactics is elaborating ways to empower a generation of women (and men) who grew up in everyday anti-feminist discourse claiming equality has been achieved and sexism is no longer an issue.

\section{Conclusion}

FEMEN represents a figuration of feminism within girl power media culture. It deliberately incorporates the codes of neoliberal consumerism to spread images of activists' breasts painted with contestation messages over all communication networks available. FEMEN activists do not refuse to be publicized and exposed. Instead; they look for attention as a means to exist: "être dans les journaux, c'est exister" [to be in newspapers is to exist] (Inna Shevchenko quoted in Timmerman, 9, my translation). This form of political practice is successful in propelling women's issues and feminist questions to the 
forefront of the media while creating an imagery of strong independent women unafraid to engage with precepts of femininity and sexuality. It inscribes women within the public sphere, where they have troubles to exist, by appropriating the streets and the media as spaces to free themselves from domination. FEMEN rejuvenates the image of feminism perceived as static and trapped within intellectual discourses with its actions and aesthetics.

Researcher Christine Fauré supports FEMEN's will to move feminism away from intellectual polemics, and towards practical action and visibility. The feminist practices of FEMEN swap theoretical texts for visual actions in the mediated public sphere. The activists' conception of femininity, their denunciation of women's mistreatments, and their claims for justice and equality is expressed through performances close to street art and body art (Fauré).

FEMEN causes a stir in France and creates a strong response in the public and amongst feminists. It has been accused of Islamophobia and neocolonialism, and criticized for its disregard of local feminism and lack of clear objectives. In addition, trials, fines, and internal tensions are growing heavy on the collective. Journalists already foresee the end of the group, especially after the departure of two founding members, Oxana Shachko and Sasha Shevchenko (not related to Inna) from FEMEN France to only be part of FEMEN International (Tayler; Girard “Les FEMEN”). However, FEMEN's neoliberal tactics have a deep and transformative impact on feminism and activism. 
FEMEN embodies an a[ttra]ctive contemporary feminist group borrowing elements of third-wave feminism while going towards new transformations in feminist articulations. Within its contribution to the mutation of contemporary feminism, FEMEN instigates media-driven activist actions unafraid to shift stricter ideals about sexual objectification to reappropriate them, play with codes and norms to display rebellious images at a local level as well as a global level. FEMEN is changing the notion of activism altogether, bringing it closer to everyday actions individuals can take on their own platforms of social media while linking it to globalized ideals. Actions à la FEMEN are conducted by women around the world, such as Ai Xiaoming, or Aliaa Magda Elmahdy, without being part of the group. These transnational bodies actually risk more than FEMEN activists and nourish a feminist practice beyond race and age.

FEMEN could improve its political stance in many ways, for instance, by elaborating a clear critique of the objectification of female bodies, or thinking about imperialist colonizing practices and how to go beyond them. It could also learn from the new forms of activism and empowerment FEMEN inspires on a global scale. FEMEN's visibility invites - or may even force - us to think about political action within the consumerist society in which it is set. Taking advantage of the communicational tools of contemporary media allows to publicize non-mainstream issues more effectively and, potentially, to reappropriate the codes that regulate visibility. From these powerful means of reaching a majority of the public, we can envision a transformation in how political action is conducted both at an individual and a collective level. It would 
even be thinkable to turn neoliberal codes of consumption on its head using its own methods. 


\section{Works Cited}

Bard, Christine. “'Mon corps est une arme,' des suffragettes aux FEMEN.” Les

Temps Modernes 678.2 (2014): 213-240. Web. CAIRN. 7 May 2015.

Brouze, Émilie and Renée Greusard. "Seins nus: les FEMEN, phénomène médiatique ou féministe?” Rue89.fr. Le Nouvel Observateur partenaire Rue89, 23 Dec. 2012. Web. 25 May 2015.

Chollet, Mona. "FEMEN partout, féminisme nulle part." Le Monde diplomatique 12 Mar. 2013, Web. 25 May 2015.

Cordier, Solène. “Comment sont financées les FEMEN.” Le Monde 14 Feb. 2014, Web. 25 May 2015.

Clairouin, Olivier and Elisabeth Barthet. "Seins nus et slogans choc: le coup médiatique permanent des FEMEN.” Le Monde 16 Oct. 2012. Web. 25 May 2015.

Dalibert, Marion et Nelly Quemener. "FEMEN, l'émancipation par les seins nus?” Hermès, la revue 69.2 (2014): 169-173. Web. CAIRN. 25 May 2015. PDF.

Daumas, Cécile et Quentin Girard. "Des amazones aux actions kamikazes." Libération 6 Jun. 2013. Web. 25 May 2015.

Desnos, Marie. "FEMEN. Au commencement était la femme." Paris Match 18 Sept. 2013. Web. 25 May 2015.

Eileraas, Karina. "Sex(t)ing Revolution, FEMEN-izing the Public Square: Aliaa Magda Elmahdy, Nude Protest, and Transnational Feminist Body Politics." Signs 40.1 (2014): 40-52. Web. Jstor. 25 May 2015.

Fauré, Christine. "Le planisphère des FEMEN.” Les Temps Modernes 3 (2013) : 377-88. Web. 25 May 2015.

FEMEN. 2015. Web. 25 May 2015.

Girard, Quentin. "Viktor Sviatski, un manipulateur dans l'ombre des FEMEN." Libération 4 Sept. 2013. Web. 25 May 2015. 
-----. “Les FEMEN, combien de divisions?” Libération 18 Sept. 2014. Web. 25 May 2015.

Guenifi, Asma. "Le discours des FEMEN repose sur la misandrie." Terrafemina 15 Mar. 2013. Web. 25 May 2015.

Guinhut, Hélène. « Droit à l'ivg: l'archevêque de Madrid attaqué par les FEMEN. » Elle 3 Feb. 2014. Web. 25 May 2015.

Macnab, Geoffrey. "The man who made FEMEN: New film outs Victor Svyatski as the mastermind behind the protest group and its breast-baring stunts." The Independant 3 Sept. 2013. Web. 25 May 2015.

O'Keefe, Theresa. "My body is my manifesto! Slutwalk, FEMEN and femmenist protest." Feminist Review 107 (2014): 1-19. Web. 25 May 2015.

Ovidie. "Pourquoi je n'ai plus foi en les FEMEN." Le ticket de métro d'Ovidie. MetroNews, 8 Mar. 2013. Web. 25 May 2015.

Pyzik, Agata. "Lost in Translation.” New Humanist 128.6 (2013): 32-35. Web. 25 May 2015.

Rojo, Jaime and Steven Harrington. "Culture Jamming Street Artist COMBO Stages Topless Spectacle in Paris." The Huffington Post 18 July 2013. Web. 25 May 2015.

Shevchenko, Inna. "Sextremism: The New Way for Feminism to Be!" The Huffington Post 7 Feb. 2013. Web. 25 May 2015.

Smith-Prei, Carrie. "Knaller-Sex für alle': Popfeminist Body Politics in Lady Bitch Ray, Charlotte Roche, and Sarah Kuttner." Studies in 2oth \& 21st Century Literature 35.1 (2011): 18-39. Print.

Tayler, Jeffrey. “Is FEMEN Dying?” The Atlantic 22 Aug. 2014. Web. 25 May 2015 .

Timmerman, Gaëlle. "FEMEN: une nouvelle forme de militantisme? À quel prix et avec quelle efficacité? ” Analyses \& Études 7 (2013): 1-20. Web. 25 May 2015 . 
TumulTueuses, Les. “Ha, les FEMEN...” TumulTueuses.com. 24 Jan. 2013. Web. 25 May 2015. PDF.

Ukraine is not a Brothel. Dir. Kitty Green. Film Platform, 2014. DVD.

Zaslow, Emilie. Feminism, Inc. Coming of Age in Girl Power Media Culture. New York: Palgrave, 2009. Print.

Marine Gheno is a PhD student at the University of Alberta. Her doctoral thesis focuses on scandalous women authors of novels, comics, and TV series in France and Québec. She published articles on aurélia aurita, Judith Forest, the TV series Hard, and Nelly Arcan. Her main areas of interest are scandals, media studies, women's writing, and contemporary feminism.

gheno@ualberta.ca 